\title{
Effect of Ketone Infusions on Amino Acid and Nitrogen Metabolism in Man
}

\author{
Robert S. Sherwin, Rosa G. Hendler, and Philip Felig \\ From the Department of Internal Medicine, Yale University School of Medicine, \\ New Haven, Connecticut 06510
}

A в S T R A C T To evaluate the role of hyperketonemia in the hypoalaninemia and decreased protein catabolism of prolonged starvation, $\mathrm{Na} \mathrm{DL}-\beta$-hydroxybutyrate was administered as a primed continuous $3-6-h$ infusion in nonobese subjects and in obese subjects in the postabsorptive state and after 3 days and $3-5 \frac{1}{2}$ wk of starvation. An additional obese group received 12-h ketone infusions on 2 consecutive days after 5-10 wk of fasting.

The ketone infusion in nonobese and obese subjects studied in the postabsorptive state resulted in total blood ketone acid levels of 1.1-1.2 mM, a 5-15 mg/100 ml decrease in plasma glucose, and unchanged levels of insulin, glucagon, lactate, and pyruvate. Plasma alanine fell by $21 \%(P<0.001)$ in $3 \mathrm{~h}$. In contrast, other amino acids were stable or varied by less than $10 \%$. Infusions lasting $6 \mathrm{~h}$ reduced plasma alanine by $37 \%$, reaching levels comparable to those observed in prolonged starvation. Equimolar infusions of $\mathrm{NaCl}$ and/or administration of $\mathrm{NaHCO}_{3}$ failed to alter plasma alanine levels.

During prolonged fasting, plasma alanine, which had fallen by $40 \%$ below prefast levels, fell an additional $30 \%$ in response to the ketone infusion. In association with repeated prolonged $(12 \mathrm{~h})$ infusions in subjects fasted 5-10 wk, urinary nitrogen excretion fell by $30 \%$, returning to base line after cessation of the infusions and paralleling the changes in plasma alanine. Ketone infusions resulted in two- to fourfold greater increments in blood ketone acids in fasted as compared to postabsorptive subjects.

It is concluded that increased blood ketone acid levels induced by infusions of $\mathrm{Na}$ DL- $\beta$-hydroxybutyrate result

This work was presented in part at the 66th Annual Meeting of the American Society for Clinical Investigation, Atlantic City, N. J., May 1974.

Dr. Felig is recipient of a Research Career Development Award (AM 70219) from the National Institutes of Health. Received for publication 11 Novcmber 1974 and in revised form 27 January 1975. in hypoalaninemia and in nitrogen conservation in starvation. These data suggest that hyperketonemia may be a contributory factor in the decreased availability of circulating alanine and reduction in protein catabolism characteristic of prolonged fasting.

\section{INTRODUCTION}

In fasting man survival is dependent upon the conservation of body protein stores as well as the continuous supply of energy-yielding fuels for brain metabolism (1). The need for gluconeogenesis and concomitantly the rate of protein breakdown progressively decline in prolonged starvation as ketone acids replace glucose as the major fuel consumed by the brain (2). The diminution in hepatic gluconeogenesis in prolonged fasting is mediated by a reduction in circulating glucogenic amino acids, particularly alanine, and a decrease in the outflow of these amino acids from muscle $(3,4)$. After a prolonged fast, plasma alanine decreases to a greater extent than that of all other amino acids, while splanchnic uptake and peripheral release of alanine are reduced to less than $50 \%$ of postabsorptive levels $(3,4)$. The mechanism of this decrease in alanine availability in starvation has not been established. Neither decreases in plasma insulin $(5,6)$ nor transient increases in plasma glucagon $(7)$ and growth hormone $(5,8)$ can account for the progressive decline in circulating alanine levels and nitrogen catabolism observed in prolonged starvation. In the present study $\beta$-hydroxybutyrate $\left(\beta_{-} \mathrm{OHB}\right)^{1}$ infusions were used to investigate the effect of hyperketonemia on circulating concentrations of amino acids in postabsorptive and fasted man. In addition, prolonged infusions of ketones were administered for two consecutive days to subjects fasted 5 or more wk to determine whether changes in ketone acid

${ }^{1}$ Abbreviations used in this paper: AcAc, acetoacetate; $\mathrm{Na}$ DL- $\beta$-OHB, sodium DL- $\beta$-hydroxybutyrate; $\beta$-OHB, $\beta$ hydroxybutyrate. 
concentrations can influence nitrogen excretion and protein catabolism in starvation.

\section{METHODS}

Subjects. Two groups of subjects were studied. The first group consisted of nine healthy, nonobese volunteers (six males and three females) within $10 \%$ of ideal body weight (based on 1959 Metropolitan Life Insurance Company Tables). The subjects ranged in age from 21-31 yr. They consumed weight-maintaining diets containing a minimum of $200 \mathrm{~g}$ of carbohydrate and were taking no drugs. All had negative family histories for diabetes mellitus and none had an elevated fasting plasma glucose. The second group consisted of 10 healthy obese subjects ( 3 males and 7 females) who were hospitalized at the Clinical Research Center of the Yale-NewHaven Hospital. Each had volunteered to undergo prolonged fasting after failure of dietary therapy. They were $33-176 \% \quad(106 \pm 15 \%$, mean $\pm \mathrm{SE}$ ) above ideal weight (based on 1959 Metropolitan Life Insurance Company Tables), and ranged in age from 19 to 38 yr. 9 of the 10 obese subjects had a normal plasma glucose response to $100 \mathrm{~g}$ of oral glucose $(9)$; one subject had mild glucose intolerance $(2 \mathrm{~h}$ plasma glucose $156 \mathrm{mg} /$ $100 \mathrm{ml}$ ) with a normal fasting plasma glucose. All had normal serum thyroxine levels, and normal renal and hepatic function. For at least 3 days before study they consumed a 3,000-kcal diet containing $300 \mathrm{~g}$ of carbohydrate and $125 \mathrm{~g}$ of protein and were taking no drugs.

The subjects were informed of the nature, purpose, and possible risks of the study before obtaining their written voluntary consent to participate. Daily intake during fasting was restricted to $2,000 \mathrm{ml}$ of water, one multivitamin tablet (Theragran, E. R. Squibb \& Sons, New York), $1 \mathrm{mg}$ of folic acid (Volvite, American Cyanamid Co., Lederle Laboratories Div., Pearl River, N. Y.), and intermittently 650 $\mathrm{mg}$ of sodium bicarbonate (sugar free) and $20 \mathrm{meq}$ of potassium gluconate (Kaon, Warren-Teed Products [Pharmaceuticals], Columbus, Ohio). No potassium gluconate was administered for 7 days before, during, or for 4 days after the infusion of ketones.

Procedures. The nonobese volunteers were studied after a 12-15-h fast (postabsorptive state). A total of 10 ketone infusions were performed in this group (one subject was studied on two occasions). The obese subjects were studied in the postabsorptive state $(n=5)$, after a 3-day fast $(n=$ $3)$, and after a $3-5 \frac{1}{2}$-wk fast $(n=4)$. An additional obese group $(n=5)$ was studied with prolonged $(12 \mathrm{~h})$ infusions after $5-10 \mathrm{wk}$ of starvation (see below).

An indwelling catheter was inserted in an antecubital vein for blood sampling and in the contralateral vein for administration of sodium DL- $\beta$-hydroxybutyrate ( Na DL- $\beta$ OHB). The NabL- $\beta$-OHB utilized for the infusion (obtained from Nutritional Biochemical Co., Cleveland, Ohio) was prepared as a $40 \%$ solution in sterile water, passed through a $22 \mu \mathrm{m}$ filter apparatus (Millipore Corp., Bedford, Mass.) and stored at $4^{\circ} \mathrm{C}$ until used. Each lot was tested for pyrogen (10) and cultured for bacterial contamination before use. Before administration, sterile, pyrogen-free water was added to the $\mathrm{Na}$ DL- $\beta$-OHB solution to achieve a final solute concentration in the infusate which varied between 3.6 and $7.1 \mathrm{~g} / 100 \mathrm{ml}$. By varying the ketone concentration in the infusate, a standard continuous delivery rate (3.9 $\mathrm{ml} / \mathrm{min}$ ) was employed in all subjects.

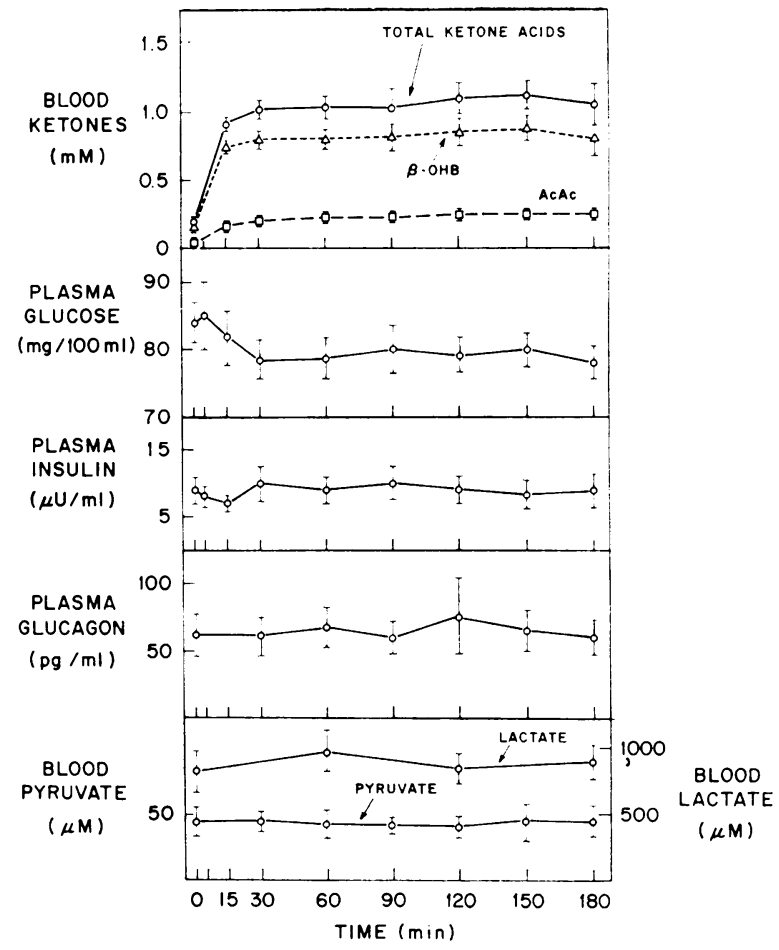

Figl'RE 1 Effect of $\beta$-OHB infusion ( $3 \mathrm{~h}$ ) on blood ketone acids, lactate, and pyruvate and plasma glucose, insulin, and glucagon concentrations (mean $\pm \mathrm{SE}$ ) in postabsorptive nonobese subjects. The basal data ( 0 time) represent the mean of two observations at $15-\mathrm{min}$ intervals.

The ketone solution was administered as a primed-continuous infusion via a peristaltic infusion pump (Harvard Apparatus Co., Inc., Millis, Mass.). The priming dose was given over the initial 20 -min period at twice the continuous infusion dose. The continuous infusion dose in nonobese subjects was $3 \mathrm{mg} / \mathrm{kg}$ body weight per min administered for $3 \mathrm{~h}$. The dose in the obese subjects was $110 \mathrm{mg} / \mathrm{m}^{2}$ body surface area per min administered for $6 \mathrm{~h}$. Eight additional healthy subjects were studied in the postabsorptive state during the infusion of sodium chloride or sodium bicarbonate under conditions identical with those employed for the ketone infusions. Four of the subjects received infusions of sodium chloride $(\mathrm{NaCl})$ in amounts equimolar to the $\mathrm{Na} \mathrm{DL}-\beta-\mathrm{OHB}$ infusion. Four subjects received an infusion of sodium bicarbonate $\left(\mathrm{NaHCO}_{3}\right)$ to deliver approximately $100-135$ meq of $\mathrm{NaHCO}_{3}$. This amount of bicarbonate was chosen to produce an increment in serum bicarbonate similar to that observed with the infusion of $\mathrm{Na}$ DL- $\beta$-OHB (see Results, below).

After the subjects had been resting in the recumbent position for a minimum of $30 \mathrm{~min}$, at least two base-line blood samples were drawn at 15 -min intervals before initiation of the infusion; additional blood samples were drawn at 5, 15, and $30 \mathrm{~min}$ after the start of the infusion and at 30 -min intervals thereafter until completion of the infusion at 180 min. Blood samples were also obtained from the obese subjects after the infusion was discontinued for amino acid measurements in order to follow the time-course of the postinfusion response. 
TABLE I

Plasma Concentrations of Amino Acids during a 3-h Intravenous Infusion of $\mathrm{Na} D L-\beta-O H B$ in Nonobese Subjects*

\begin{tabular}{|c|c|c|c|c|c|c|}
\hline Amino acid & $0 \ddagger \mathrm{min}$ & $30 \mathrm{~min}$ & $60 \mathrm{~min}$ & $120 \mathrm{~min}$ & $150 \mathrm{~min}$ & $180 \mathrm{~min}$ \\
\hline & $\mu M$ & $\mu M$ & $\mu M$ & $\mu M$ & $\mu M$ & $\mu M$ \\
\hline Taurine & $40 \pm 3$ & $40 \pm 4$ & $40 \pm 4$ & $39 \pm 3$ & $36 \pm 4$ & $39 \pm 7$ \\
\hline Threonine & $137 \pm 11$ & $128 \pm 17$ & $141 \pm 13$ & $133 \pm 13$ & $131 \pm 13$ & $\begin{array}{c}128 \pm 13 \\
P<0.05 \S\end{array}$ \\
\hline Serine & $118 \pm 0$ & $114 \pm 10$ & $116 \pm 10$ & $107 \pm 9$ & $\begin{array}{r}108 \pm 10 \\
P<0.05\end{array}$ & $\begin{array}{r}104 \pm 11 \\
P<0.02\end{array}$ \\
\hline Proline & $169 \pm 16$ & $\begin{array}{c}178 \pm 12 \\
P<0.05\end{array}$ & $\begin{array}{c}180 \pm 15 \\
P<0.02\end{array}$ & $172 \pm 16$ & $162 \pm 18$ & $163 \pm 17$ \\
\hline Citruilline & $38 \pm 5$ & $39 \pm 7$ & $37 \pm 5$ & $36 \pm 5$ & $\begin{array}{c}32 \pm 5 \\
P<0.05\end{array}$ & $36 \pm 6$ \\
\hline Glycine & $215 \pm 19$ & $199 \pm 19$ & $217 \pm 19$ & $209 \pm 17$ & $\begin{array}{r}204 \pm 19 \\
P<0.05\end{array}$ & $\begin{array}{r}201 \pm 17 \\
P<0.05\end{array}$ \\
\hline Alanine & $289 \pm 24$ & $271 \pm 34$ & $\begin{array}{c}272 \pm 23 \\
P<0.05\end{array}$ & $\begin{array}{c}250 \pm 25 \\
P<0.001\end{array}$ & $\begin{array}{c}242 \pm 24 \\
P<0.001\end{array}$ & $\begin{array}{c}233 \pm 21 \\
P<0.001\end{array}$ \\
\hline$\alpha$-aminobutyrate & $20 \pm 2$ & $20 \pm 4$ & $22 \pm 3$ & $23 \pm 4$ & $22 \pm 3$ & $21 \pm 3$ \\
\hline Valine & $197 \pm 13$ & $199 \pm 18$ & $202 \pm 14$ & $193 \pm 14$ & $199 \pm 14$ & $196 \pm 12$ \\
\hline Cystine & $87 \pm 8$ & $77 \pm 12$ & $96 \pm 8$ & $80 \pm 10$ & $82 \pm 10$ & $81 \pm 8$ \\
\hline Methionine & $26 \pm 2$ & $23 \pm 3$ & $27 \pm 2$ & $26 \pm 3$ & $\begin{array}{c}21 \pm 2 \\
P<0.02\end{array}$ & $24 \pm 2$ \\
\hline Leucine & $116 \pm 8$ & $119 \pm 13$ & $122 \pm 10$ & $118 \pm 9$ & $116 \pm 9$ & $113 \pm 8$ \\
\hline Isoleucine & $65 \pm 5$ & $68 \pm 9$ & $68 \pm 6$ & $64 \pm 5$ & $61 \pm 5$ & $60 \pm 4$ \\
\hline Tyrosine & $52 \pm 4$ & $49 \pm 5$ & $52 \pm 5$ & $48 \pm 4$ & $47 \pm 4$ & $48 \pm 6$ \\
\hline Phenylalanine & $50 \pm 3$ & $50 \pm 6$ & $53 \pm 5$ & $52 \pm 4$ & $53 \pm 5$ & $53 \pm 5$ \\
\hline
\end{tabular}

* Data presented as mean $\pm \mathrm{SE}$.

$\ddagger$ Control values represent the mean of two observations on each subject preceding $\mathrm{Na}$ DL- $\beta$-OHB administration. $\S P$ values refer to significance of difference from time "0" (paired $t$ test). Only values which differ significantly are indicated.

To determine the effects of hyperketonemia on protein catabolism during starvation, as reflected by urinary nitrogen excretion, five additional obese subjects were given prolonged $(12 \mathrm{~h})$ infusions of $\mathrm{Na}$ DL- $\beta$-OHB on 2 consecutive days after $5-10 \mathrm{wk}$ of starvation. The dose of ketone acids was $55 \mathrm{mg} / \mathrm{m}^{2}$ body surface area per min given i.v. as a continuous infusion (by peristaltic pump) between 9:00 a.m. and 9:00 p.m. The subjects continued to fast for 4 days after completion of the infusions. Blood samples were drawn before, upon completion of the infusions, and at 9:00 a.m. on days 1,3 , and 4 of the 4 days postinfusion. Urine was collected in refrigerated containers for $24 \mathrm{~h}$ periods $(9: 00$ a.m. $-9: 00$ a.m.) beginning 4 days before ketone administration (preinfusion period), during the 2-day infusion period, and for 4 days" after ketone administration (postinfusion period). Values for each subject's daily urine nitrogen excretion during and after the ketone infusions were compared with the mean of the 4 preinfusion values.

Analyses. The methods employed for the determination of plasma glucose, plasma immunoreactive insulin, plasma immunoreactive glucagon, (using Unger antibody $30 \mathrm{~K}$ ) and plasma acidic and neutral amino acids have been described previously (11). $\mathbf{D}(-)-\beta$-hydroxybutyrate and acetoacetate (AcAc) were measured in blood according to the method of Williamson, Mellanby, and Krebs (12). Blood pyruvate was determined on the day of the study by a modification of the method of Bücher, Czok, Lamprecht, and Latzko (13), and blood lactate was determined using an enzymatic assay (14). Total nitrogen in urine was determined in duplicate by the standard Kjeldahl technique. Urinary urea nitrogen and ammonia nitrogen were measured by the urease method (15) and urinary creatinine by the picric acid method (16). - For the statistical analyses, the paired $t$ test (17) was used. Data are presented as the mean $\pm \mathrm{SE}$.

\section{RESULTS}

Response to ketone infusion in nonobese subjects. Fig. 1 demonstrates the changes in blood ketones, lactate, and pyruvate, and in plasma glucose, insulin, and glucagon produced by the infusion of $\mathrm{Na}$ DL- $\beta-\mathrm{OHB}$ in normal subjects. Ketone acid levels increased rapidly, 
reaching a plateau at 30-60 min. Mean concentrations between $1-3 \mathrm{~h}$ were $0.84 \pm 0.09 \mathrm{mM}$ for $\beta$-OHB, $0.24 \pm$ $0.02 \mathrm{mM}$ for AcAc, and $1.08 \pm 0.11 \mathrm{mM}$ for total ketones. The $\beta_{-} \mathrm{OHB} / \mathrm{AcAc}$ ratio was $3.4 \pm 0.4$ in the basal state and was not significantly altered by the infusion (3.5 \pm $0.3)$. As anticipated (18), there was a small (5-10 $\mathrm{mg} / 100 \mathrm{ml})$ but significant $(P<0.01)$ decrease in plasma glucose which was maximal at 30 min and persisted throughout the $3-\mathrm{h}$ study period. The mean maximal glucose decrement averaged $8 \pm 2 \mathrm{mg} / 100 \mathrm{ml}$. Plasma insulin and glucagon concentrations were unchanged. Blood lactate and pyruvate concentrations were measured during the ketone infusion to determine if significant shifts in redox state were induced (Fig. 1). Neither the concentration of pyruvate nor lactate was altered by $\mathrm{Na}$ DL- $\beta$-OHB administration. Serum bicarbonate which was $26 \pm 1 \mathrm{meq} / \mathrm{liter}$ in the basal state rose by $5 \pm 1 \mathrm{meq} / \mathrm{liter}$ at termination of the infusion.

The effect of hyperketonemia on plasma amino acid concentrations is summarized in Table I. Plasma alanine fell significantly at $1 \mathrm{~h}$ and decreased progressively during the study period. The mean maximal decline in alanine was $21 \pm 2 \%$. In contrast to alanine, the concentrations of other amino acids were unchanged, or in the case of threonine, serine, and glycine fell by less than $10 \%$.

To exclude the possibility that the fall in plasma alanine was a consequence of either plasma volume expansion or ketone-induced alkalosis, the effects of infusions of $\mathrm{NaCl}$ and $\mathrm{NaHCO}_{3}$ were examined. Infusion of $\mathrm{NaHCO}_{3}$ resulted in an increase in serum bicarbonate of $3 \pm 1 \mathrm{meq} /$ liter, comparable to that observed with the ketone infusion. As shown in Fig. 2, in contrast to the hypoalaninemic effect of ketones, neither infusion of $\mathrm{NaCl}$ nor $\mathrm{NaHCO}_{3}$ altered plasma alanine concentration. The concentrations of other acidic and neutral amino acids were also unchanged by these infusions.

Response to ketone infusion in postabsorptive obese subjects. The basal concentrations of ketone acids in the obese group were $0.12 \pm 0.03 \mathrm{mM}$ for $\beta-\mathrm{OHB}$ and $0.04 \pm 0.02 \mathrm{mM}$ for AcAc. These values and the ketone concentrations achieved in the obese group during the $\mathrm{Na}$ DL- $\beta$-OHB infusion were not significantly different from those observed in the nonobese group. The mean levels at $1-6 \mathrm{~h}$ of the infusion were $0.94 \pm 0.10 \mathrm{mM}$ for $\beta$-OHB, $0.25 \pm 0.02 \mathrm{mM}$ for AcAc, and $1.19 \pm 0.12 \mathrm{mM}$ for total ketones. As in the nonobese group, the obese subjects demonstrated a small decline in plasma glucose $(12 \pm 2 \mathrm{mg} / 100 \mathrm{ml}$ ), but no changes in plasma insulin or glucagon concentrations during the infusions.

The effect of $\mathrm{Na} \mathrm{DL}_{-} \beta-\mathrm{OHB}$ administration on plasma amino acid levels is shown in Table II. Plasma alanine fell $20 \%$ after $3 \mathrm{~h}$ and continued to decline as the infusion was extended for $6 \mathrm{~h}$. The mean maximal decre-

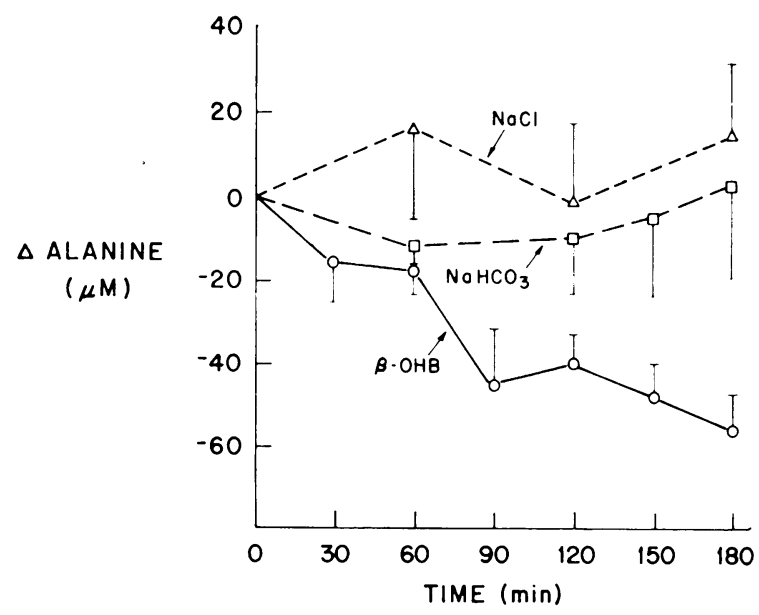

FIGLRE 2 Changes in circulating alanine (mean \pm SE) during infusion $(3 \mathrm{~h})$ of $\beta$-OHB, sodium bicarbonate, and sodium chloride in normal, postabsorptive subjects. The changes in plasma alanine during infusion of $\mathrm{NaCl}$ and $\mathrm{NaHCO}_{3}$ were not significantly different from the base-line values.

ment in alanine was $37 \pm 3 \%$. After the infusion was discontinued, plasma alanine remained depressed for an additional $4 \mathrm{~h}$ and returned toward base line at $24 \mathrm{~h}$.

With respect to other amino acids, plasma concentrations at $3 \mathrm{~h}$ were unchanged from the basal state with the exception of small declines in plasma taurine, tyrosine, and valine. These results were similar to those observed in the nonobese group. After $6 \mathrm{~h}$ there was a significant reduction in all amino acids other than leucine, isoleucine, cystine, and $\alpha$-aminobutyrate. However, the magnitude of the decrease in alanine exceeded that of all other amino acids (Table II).

Response to kctone infusion during stariation. To determine if the effects of increments in blood ketone acids on circulating amino acid levels observed in the postabsorptive state occur during fasting as well, obese subjects were studied after 3 days and $3-5 \frac{1}{2}$ wh of starvation. After a 3-day fast, base line total ketone concentrations were $1.39 \pm 0.22 \mathrm{mM}$. Infusion of $\mathrm{Na}$ DL- $\beta_{-} \mathrm{OHB}$ resulted in an increment in total ketones which was approximately twice that obtained in the postabsorptive state and which failed to reach a stable plateau even af-

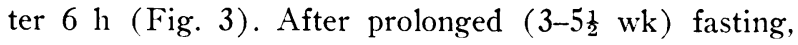
$\beta$-OHB infusion produced a progressive increase in total ketones from basal levels of $5.72 \pm 0.64 \mathrm{mM}$ to peak values of $10.39 \pm 0.91 \mathrm{mM}$. The increment in total ketones induced by the infusion was approximately four times greater than that observed in postabsorptive studies (Fig. 3). A small decline was observed in plasma gluclose $(5-8 \mathrm{mg} / 100 \mathrm{ml})$. Plasma insulin and glucagon concentrations which were $9.8 \pm 1.4 \mu \mathrm{U} / \mathrm{ml}$ and $97 \pm 21$ $\mathrm{pg} / \mathrm{ml}$, respectively, in the basal state $\left(3-5 \frac{1}{2}-\mathrm{wk}\right.$ fast) 
TABLE II

Plasma Concentrations of Amino Acids during and after a 6-h Intravenous Infusion of $N a D L-\beta-O H B$ in Obese Subjects in the Postabsorptive State and after Prolonged Fasting*

\begin{tabular}{|c|c|c|c|c|c|c|c|c|c|c|c|c|}
\hline Amino acid & $\begin{array}{l}\text { Condi- } \\
\text { tion }\end{array}$ & $0 \ddagger$ & $3 \mathrm{~h}$ & $P \S$ & $5 \mathrm{~h}$ & $P$ & $6 \mathrm{~h}$ & $P$ & $10 \mathrm{~h}$ & $P$ & $24 \mathrm{~h}$ & $P$ \\
\hline & & $\mu M$ & $\mu M$ & & $\mu M$ & & $\mu M$ & & $\mu M$ & & $\mu M$ & \\
\hline Taurine & $\begin{array}{l}P \| \\
F \|\end{array}$ & $\begin{array}{l}40 \pm 6 \\
54 \pm 4\end{array}$ & $\begin{array}{l}29 \pm 5 \\
38 \pm 6\end{array}$ & $\begin{array}{l}<0.01 \\
<0.05\end{array}$ & $\begin{array}{l}29 \pm 7 \\
37 \pm 2\end{array}$ & $\begin{array}{l}<0.02 \\
<0.01\end{array}$ & $\begin{array}{l}29 \pm 6 \\
37 \pm 2\end{array}$ & $\begin{array}{l}<0.025 \\
<0.01\end{array}$ & $36 \pm 10$ & NS & $\begin{array}{l}46 \pm 13 \\
46 \pm 4\end{array}$ & $\begin{array}{l}\text { NS } \\
\text { NS }\end{array}$ \\
\hline Threonine & $\begin{array}{l}\mathrm{P} \\
\mathrm{F}\end{array}$ & $\begin{array}{l}158 \pm 20 \\
154 \pm 16\end{array}$ & $\begin{array}{l}138 \pm 15 \\
162 \pm 15\end{array}$ & $\begin{array}{l}\text { NS } \\
\text { NS }\end{array}$ & $\begin{array}{l}123 \pm 19 \\
157 \pm 21\end{array}$ & $\begin{array}{c}<0.02 \\
\text { NS }\end{array}$ & $\begin{array}{l}117 \pm 14 \\
150 \pm 21\end{array}$ & $\begin{array}{c}<0.05 \\
\text { NS }\end{array}$ & $94 \pm 14$ & $<0.02$ & $\begin{array}{l}109 \pm 7 \\
161 \pm 22\end{array}$ & $\begin{array}{l}\text { NS } \\
\text { NS }\end{array}$ \\
\hline Serine & $\begin{array}{l}\mathbf{P} \\
\mathbf{F}\end{array}$ & $\begin{array}{l}131 \pm 11 \\
131 \pm 14\end{array}$ & $\begin{array}{l}118 \pm 20 \\
127 \pm 11\end{array}$ & $\begin{array}{l}\text { NS } \\
\text { NS }\end{array}$ & $\begin{array}{c}89 \pm 9 \\
120 \pm 18\end{array}$ & $\begin{array}{c}<0.02 \\
\text { NS }\end{array}$ & $\begin{array}{c}81 \pm 7 \\
115 \pm 15\end{array}$ & $\begin{array}{c}<0.02 \\
\text { NS }\end{array}$ & $89 \pm 6$ & $<0.02$ & $\begin{array}{l}100 \pm 9 \\
128 \pm 17\end{array}$ & $\begin{array}{l}\text { NS } \\
\text { NS }\end{array}$ \\
\hline Proline & $\begin{array}{l}\mathrm{P} \\
\mathrm{F}\end{array}$ & $\begin{array}{l}146 \pm 10 \\
127 \pm 11\end{array}$ & $\begin{array}{l}126 \pm 19 \\
132 \pm 15\end{array}$ & $\begin{array}{l}\text { NS } \\
\text { NS }\end{array}$ & $\begin{array}{l}104 \pm 7 \\
136 \pm 12\end{array}$ & $\begin{array}{c}<0.05 \\
\text { NS }\end{array}$ & $\begin{array}{l}110 \pm 16 \\
130 \pm 10\end{array}$ & $\begin{array}{c}<0.005 \\
\text { NS }\end{array}$ & $88 \pm 10$ & $<0.05$ & $\begin{array}{r}95 \pm 11 \\
143 \pm 11\end{array}$ & $\begin{array}{c}<0.05 \\
\text { NS }\end{array}$ \\
\hline Citrulline & $\begin{array}{l}P \\
F\end{array}$ & $\begin{array}{l}27 \pm 4 \\
17 \pm 3\end{array}$ & $\begin{array}{l}24 \pm 5 \\
16 \pm 2\end{array}$ & $\begin{array}{l}\text { NS } \\
\text { NS }\end{array}$ & $\begin{array}{l}22 \pm 4 \\
15 \pm 2\end{array}$ & $\begin{array}{l}\text { NS } \\
\text { NS }\end{array}$ & $\begin{array}{l}22 \pm 5 \\
16 \pm 4\end{array}$ & $\begin{array}{c}<0.05 \\
\text { NS }\end{array}$ & $20 \pm 6$ & $<0.05$ & $\begin{array}{l}23 \pm 5 \\
15 \pm 2\end{array}$ & $\begin{array}{c}<0.025 \\
\text { NS }\end{array}$ \\
\hline Glycine & $\begin{array}{l}P \\
F\end{array}$ & $\begin{array}{l}192 \pm 16 \\
261 \pm 19\end{array}$ & $\begin{array}{l}184 \pm 14 \\
268 \pm 14\end{array}$ & $\begin{array}{l}\text { NS } \\
\text { NS }\end{array}$ & $\begin{array}{l}157 \pm 16 \\
259 \pm 13\end{array}$ & $\begin{array}{c}<0.02 \\
\text { NS }\end{array}$ & $\begin{array}{l}148 \pm 10 \\
252 \pm 11\end{array}$ & $\begin{array}{c}<0.05 \\
\text { NS }\end{array}$ & $139 \pm 18$ & $<0.02$ & $\begin{array}{l}168 \pm 13 \\
269 \pm 13\end{array}$ & $\begin{array}{l}\text { NS } \\
\text { NS }\end{array}$ \\
\hline Alanine & $\begin{array}{l}\mathrm{P} \\
\mathrm{F}\end{array}$ & $\begin{array}{l}318 \pm 19 \\
195 \pm 11\end{array}$ & $\begin{array}{l}255 \pm 20 \\
145 \pm 7\end{array}$ & $\begin{array}{l}<0.02 \\
<0.05\end{array}$ & $\begin{array}{l}230 \pm 19 \\
144 \pm 14\end{array}$ & $\begin{array}{c}<0.01 \\
\text { NS }\end{array}$ & $\begin{array}{l}225 \pm 16 \\
141 \pm 7\end{array}$ & $\begin{array}{l}<0.01 \\
<0.05\end{array}$ & $216 \pm 21$ & $<0.001$ & $\begin{array}{l}283 \pm 16 \\
189 \pm 12\end{array}$ & $\begin{array}{c}<0.05 \\
\text { NS }\end{array}$ \\
\hline $\boldsymbol{\alpha}$-aminobutyrate & $\begin{array}{l}\mathrm{P} \\
\mathrm{F}\end{array}$ & $\begin{array}{l}33 \pm 8 \\
44 \pm 9\end{array}$ & $\begin{array}{l}31 \pm 8 \\
41 \pm 9\end{array}$ & $\begin{array}{l}\text { NS } \\
\text { NS }\end{array}$ & $\begin{array}{l}23 \pm 5 \\
40 \pm 7\end{array}$ & $\begin{array}{l}\text { NS } \\
\text { NS }\end{array}$ & $\begin{array}{l}22 \pm 4 \\
42 \pm 8\end{array}$ & $\begin{array}{l}\text { NS } \\
\text { NS }\end{array}$ & $25 \pm 6$ & NS & $\begin{array}{l}31 \pm 9 \\
45 \pm 5\end{array}$ & $\begin{array}{l}\text { NS } \\
\text { NS }\end{array}$ \\
\hline Valine & $\begin{array}{l}P \\
F\end{array}$ & $\begin{array}{l}257 \pm 15 \\
196 \pm 24\end{array}$ & $\begin{array}{l}237 \pm 13 \\
199 \pm 20\end{array}$ & $\begin{array}{l}<0.05 \\
\text { NS }\end{array}$ & $\begin{array}{l}220 \pm 7 \\
201 \pm 21\end{array}$ & $\begin{array}{l}\text { NS } \\
\text { NS }\end{array}$ & $\begin{array}{l}213 \pm 5 \\
199 \pm 20\end{array}$ & $\begin{array}{c}<0.05 \\
\text { NS }\end{array}$ & $215 \pm 7$ & $<0.02$ & $\begin{array}{l}228 \pm 14 \\
213 \pm 18\end{array}$ & $\begin{array}{l}\text { NS } \\
\text { NS }\end{array}$ \\
\hline Cystine & $\begin{array}{l}\mathbf{P} \\
\mathbf{F}\end{array}$ & $\begin{array}{l}113 \pm 11 \\
109 \pm 9\end{array}$ & $\begin{array}{r}119 \pm 19 \\
99 \pm 10\end{array}$ & $\begin{array}{l}\text { NS } \\
\text { NS }\end{array}$ & $\begin{array}{l}107 \pm 17 \\
104 \pm 16\end{array}$ & $\begin{array}{l}\text { NS } \\
\text { NS }\end{array}$ & $\begin{array}{r}87 \pm 19 \\
100 \pm 21\end{array}$ & $\begin{array}{l}\text { NS } \\
\text { NS }\end{array}$ & $113 \pm 20$ & NS & $\begin{array}{l}118 \pm 20 \\
133 \pm 10\end{array}$ & $\begin{array}{l}\text { NS } \\
\text { NS }\end{array}$ \\
\hline Methionine & $\begin{array}{l}\mathrm{P} \\
\mathrm{F}\end{array}$ & $\begin{array}{l}26 \pm 3 \\
27 \pm 2\end{array}$ & $\begin{array}{l}21 \pm 2 \\
25 \pm 3\end{array}$ & $\begin{array}{l}\text { NS } \\
\text { NS }\end{array}$ & $\begin{array}{l}18 \pm 3 \\
27 \pm 3\end{array}$ & $\begin{array}{c}<0.02 \\
\text { NS }\end{array}$ & $\begin{array}{l}21 \pm 3 \\
25 \pm 2\end{array}$ & $\begin{array}{c}<0.05 \\
\text { NS }\end{array}$ & $17 \pm 3$ & $<0.02$ & $\begin{array}{l}27 \pm 3 \\
27 \pm 3\end{array}$ & $\begin{array}{l}\text { NS } \\
\text { NS }\end{array}$ \\
\hline Leucine & $\begin{array}{l}\mathrm{P} \\
\mathrm{F}\end{array}$ & $\begin{array}{l}123 \pm 20 \\
130 \pm 15\end{array}$ & $\begin{array}{l}119 \pm 21 \\
141 \pm 15\end{array}$ & $\begin{array}{l}\text { NS } \\
\text { NS }\end{array}$ & $\begin{array}{l}104 \pm 17 \\
144 \pm 12\end{array}$ & $\begin{array}{l}\text { NS } \\
\text { NS }\end{array}$ & $\begin{array}{l}105 \pm 11 \\
146 \pm 13\end{array}$ & $\begin{array}{l}\text { NS } \\
\text { NS }\end{array}$ & $108 \pm 9$ & NS & $\begin{array}{l}116 \pm 8 \\
144 \pm 20\end{array}$ & $\begin{array}{l}\text { NS } \\
\text { NS }\end{array}$ \\
\hline Isoleucine & $\begin{array}{l}\mathrm{P} \\
\mathrm{F}\end{array}$ & $\begin{array}{l}82 \pm 16 \\
85 \pm 8\end{array}$ & $\begin{array}{l}72 \pm 11 \\
85 \pm 12\end{array}$ & $\begin{array}{l}\text { NS } \\
\text { NS }\end{array}$ & $\begin{array}{l}71 \pm 16 \\
95 \pm 8\end{array}$ & $\begin{array}{l}\text { NS } \\
\text { NS }\end{array}$ & $\begin{array}{l}74 \pm 17 \\
96 \pm 9\end{array}$ & $\begin{array}{l}\text { NS } \\
\text { NS }\end{array}$ & $79 \pm 18$ & NS & $\begin{array}{r}90 \pm 23 \\
101 \pm 14\end{array}$ & $\begin{array}{c}<0.05 \\
\text { NS }\end{array}$ \\
\hline Tyrosine & $\begin{array}{l}P \\
F\end{array}$ & $\begin{array}{l}70 \pm 7 \\
53 \pm 5\end{array}$ & $\begin{array}{l}62 \pm 9 \\
53 \pm 8\end{array}$ & $\begin{array}{l}<0.05 \\
\text { NS }\end{array}$ & $\begin{array}{l}49 \pm 1 \\
48 \pm 7\end{array}$ & $\begin{array}{c}<0.005 \\
\text { NS }\end{array}$ & $\begin{array}{l}47 \pm 1 \\
52 \pm 6\end{array}$ & $\begin{array}{c}<0.005 \\
\text { NS }\end{array}$ & $43 \pm 1$ & $<0.001$ & $\begin{array}{l}48 \pm 2 \\
52 \pm 7\end{array}$ & $\begin{array}{c}<0.005 \\
\text { NS }\end{array}$ \\
\hline Phenylalanine & $\begin{array}{l}P \\
F\end{array}$ & $\begin{array}{l}62 \pm 5 \\
52 \pm 5\end{array}$ & $\begin{array}{l}61 \pm 9 \\
55 \pm 6\end{array}$ & $\begin{array}{l}\text { NS } \\
\text { NS }\end{array}$ & $\begin{array}{l}51 \pm 2 \\
55 \pm 5\end{array}$ & $\begin{array}{c}<0.01 \\
\text { NS }\end{array}$ & $\begin{array}{l}51 \pm 3 \\
53 \pm 4\end{array}$ & $\begin{array}{c}<0.02 \\
\text { NS }\end{array}$ & $49 \pm 1$ & $<0.02$ & $\begin{array}{l}55 \pm 3 \\
54 \pm 5\end{array}$ & $\begin{array}{l}\text { NS } \\
\text { NS }\end{array}$ \\
\hline
\end{tabular}

* Data presented as mean $\pm \mathrm{SE}$.

$\ddagger$ Preinfusion values represent the mean of two observations in each subject preceding Na DL- $\beta-\mathrm{OHB}$ administration.

$\$ P$ values refer to significance of difference from preinfusion values (paired $t$ test).

II Indicates postabsorptive state.

TI Indicates studies after prolonged fasting $\left(3-5 \frac{1}{2} \mathrm{wk}\right)$.

remained unchanged throughout the infusion (final values: insulin $9.8 \pm 1.3 \mu \mathrm{U} / \mathrm{ml}$; glucagon $118 \pm 32 \mathrm{pg} / \mathrm{ml}$ ).

During starvation, basal plasma alanine levels fell to $278 \pm 21 \mu \mathrm{M}$ at 3 days ( $85 \%$ of prefast levels) and to $195 \pm 11 \mu \mathrm{M}$ at $3-5 \frac{1}{2} \mathrm{wk}$ ( $60 \%$ of prefast levels). Infusion of $\mathrm{Na}$ DL- $\beta$-OHB during starvation produced a prompt decline in plasma alanine which returned to base line with cessation of the infusion (Fig. 4). The mean maximal decline in plasma alanine was $48 \pm 5 \%$ in the 3-day fasted group and $30 \pm 9 \%$ in the group fasted $3-5 \frac{1}{2} \mathrm{wk}$. In contrast to the fall in alanine, the concentrations of all other amino acids (except taurine) were unchanged by the infusion in prolonged starvation ( $\mathrm{Ta}-$ ble II).
Effect of prolonged ketone infusions on amino acid levels and nitrogen excretion during prolonged (5-10 $w k$ ) starvation. Administration of $\mathrm{Na}$ DL- $\beta-\mathrm{OHB}$ over $12 \mathrm{~h}$ on 2 consecutive days resulted in elevations in total ketones to $9.62 \pm 0.80 \mathrm{mM}$ and $9.87 \pm 0.62 \mathrm{mM}$ at the conclusion of the infusion on day 1 and day 2, respectively. The ratio of $\beta$-OHB to AcAc, which was $4.7 \pm 0.7$ before the infusion, was unchanged by ketone administration (4.6 \pm 0.4$)$. Plasma glucose and insulin were unchanged. Serum bicarbonate which was $22 \pm 1 \mathrm{meq} /$ liter before the infusion rose by $5 \pm 1 \mathrm{meq} /$ liter at completion of the infusion.

In Table III, plasma amino acid concentrations are shown before the prolonged ketone infusions, at termi- 


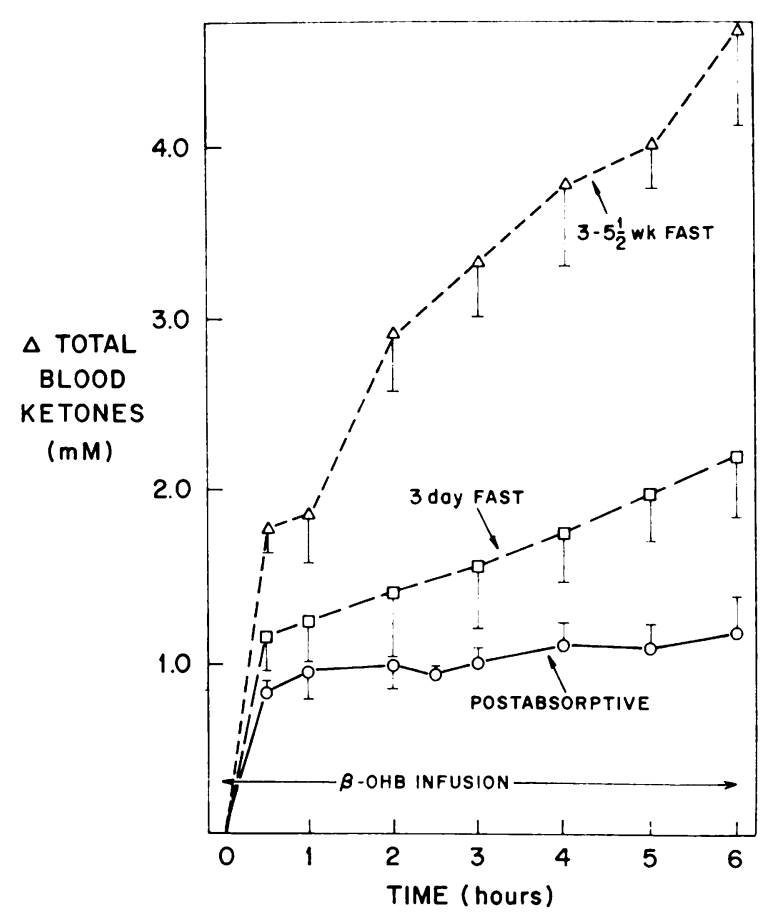

Figure 3 Changes in total blood ketone acids from basal values during infusion of $\beta$-OHB ( $110 \mathrm{mg} / \mathrm{m}^{2}$ body surface area per $\mathrm{min}$ ) in the postabsorptive state and after 3 days and $3-5 \frac{1}{2}$ wk of starvation.

nation of the infusions, and 1 day postinfusion. Plasma alanine averaged $157 \pm 22 \mu \mathrm{M}$ before ketone administration and decreased to $125 \pm 17 \mu \mathrm{M}(P<0.01)$ and $110 \pm$

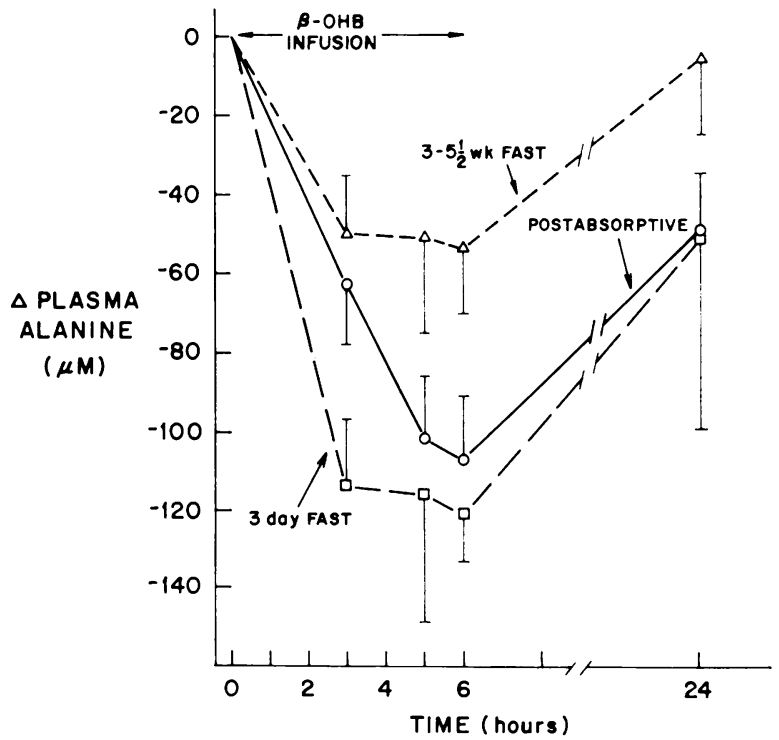

Figure 4 Changes in plasma alanine in response to infusion of $\beta-\mathrm{OHB}$ in obese subjects in postabsorptive state and after 3 days and $3-5 \frac{1}{2}$ wk of starvation. The infusion time $(6 \mathrm{~h})$ is indicated by the horizontal arrows.
TABLE III

Plasma Amino Acid Concentrations after Prolonged (12 h) Ketone Infusions in Subjects Fasted 5-10 W**

\begin{tabular}{|c|c|c|c|c|}
\hline & $\begin{array}{c}\text { Pre- } \\
\text { infusion† }\end{array}$ & $\begin{array}{l}\text { Infusion§ } \\
\text { day } 1\end{array}$ & $\begin{array}{c}\text { Infusion } \S \\
\text { day } 2\end{array}$ & $\begin{array}{c}\text { Post- } \\
\text { infusion } \|\end{array}$ \\
\hline & $\mu M$ & $\mu . M$ & $\mu M$ & $\mu M$ \\
\hline Taurine & $54 \pm 6$ & $\begin{array}{c}39 \pm 4 \\
P \stackrel{0.02 ף}{ }\end{array}$ & $46 \pm 8$ & $50 \pm 5$ \\
\hline Threonine & $190 \pm 17$ & $170 \pm 8$ & $\begin{array}{r}167 \pm 23 \\
P<0.01\end{array}$ & $178 \pm 13$ \\
\hline Serine & $100 \pm 9$ & $\begin{array}{c}77 \pm 9 \\
P<0.005\end{array}$ & $\begin{array}{c}72 \pm 9 \\
P<0.005\end{array}$ & $89 \pm 11$ \\
\hline Proline & $170 \pm 7$ & $167 \pm 8$ & $166 \pm 19$ & $160 \pm 16$ \\
\hline Citrulline & $8 \pm 2$ & $8 \pm 0$ & $8 \pm 1$ & $11 \pm 2$ \\
\hline Glycine & $301 \pm 28$ & $\begin{array}{r}271 \pm 23 \\
P<0.05\end{array}$ & $254 \pm 33$ & $275 \pm 15$ \\
\hline Alanine & $157 \pm 22$ & $\begin{array}{r}125 \pm 17 \\
P<0.01\end{array}$ & $\begin{array}{c}110 \pm 18 \\
P<0.025\end{array}$ & $125 \pm 25$ \\
\hline $\boldsymbol{\alpha}$-aminobutyrate & $33 \pm 8$ & $\begin{array}{c}26 \pm 7 \\
P<0.01\end{array}$ & $\begin{array}{c}23 \pm 10 \\
P<0.005\end{array}$ & $\begin{array}{c}26 \pm 10 \\
P<0.005\end{array}$ \\
\hline Valine & $181 \pm 33$ & $177 \pm 37$ & $171 \pm 48$ & $182 \pm 56$ \\
\hline Cystine & $86 \pm 9$ & $75 \pm 8$ & $\begin{array}{c}66 \pm 8 \\
P<0.05\end{array}$ & $77 \pm 11$ \\
\hline Methionine & $29 \pm 4$ & $24 \pm 4$ & $\begin{array}{c}26 \pm 5 \\
P<0.025\end{array}$ & $30 \pm 6$ \\
\hline Leucine & $112 \pm 27$ & $116 \pm 29$ & $113 \pm 37$ & $127 \pm 43$ \\
\hline Isoleucine & $70 \pm 17$ & $77 \pm 19$ & $\begin{array}{r}83 \pm 22 \\
P<0.01\end{array}$ & $90 \pm 26$ \\
\hline Tyrosine & $44 \pm 5$ & $\begin{array}{c}39 \pm 4 \\
P<0.05\end{array}$ & $38 \pm 5$ & $43 \pm 6$ \\
\hline Phenylalanine & $38 \pm 5$ & $35 \pm 4$ & $34 \pm 6$ & $39 \pm 7$ \\
\hline
\end{tabular}

* Data presented as mean $\pm \mathrm{SE}$.

$\ddagger$ Preinfusion values represent the mean of two observations in each subject preceding Na DL- $\beta-\mathrm{OHB}$ administration.

$\S$ Values represent concentrations obtained at the conclusion of the infusion $(12 \mathrm{~h})$.

|| Postinfusion values represent concentrations obtained 1 day after the infusion.

T $P$ values refer to significance of difference from time " 0 " (paired $t$ test) Only values which differ significantly are indicated.

$18 \mu \mathrm{M}(P<0.025)$ on day 1 and day 2 of the infusion, respectively. During the postinfusion control period, plasma alanine returned to preinfusion levels (Fig. 5). Other than alanine, consistent declines during both days of the infusion were observed only for serine and $\alpha$-aminobutyrate. A small, but significant, increase was observed in isoleucine (Table III).

In Fig. 5, data on urinary nitrogen excretion are shown. Urinary nitrogen excretion remained stable during the 4-day preinfusion control period. By the second infusion day, total nitrogen, urea nitrogen, and ammonia excretion were reduced by $26 \%, 34 \%$, and $33 \%$, respectively. Total nitrogen decreased from $3.59 \pm$ $0.21 \mathrm{~g} / \mathrm{g}$ creatinine per $24 \mathrm{~h}$ to $2.65 \pm 0.22 \mathrm{~g} / \mathrm{g}$ creatinine per $24 \mathrm{~h}(P<0.005)$; urea nitrogen fell from $1.18 \pm$ $0.34 \mathrm{~g} / \mathrm{g}$ creatinine per $24 \mathrm{~h}$ to $0.78 \pm 0.24 \mathrm{~g} / \mathrm{g}$ creatinine per $24 \mathrm{~h}(P<0.025)$; and ammonia nitrogen declined from $1.38 \pm 0.15 \mathrm{~g} / \mathrm{g}$ creatinine per $24 \mathrm{~h}$ to $0.93 \pm 0.12$ 


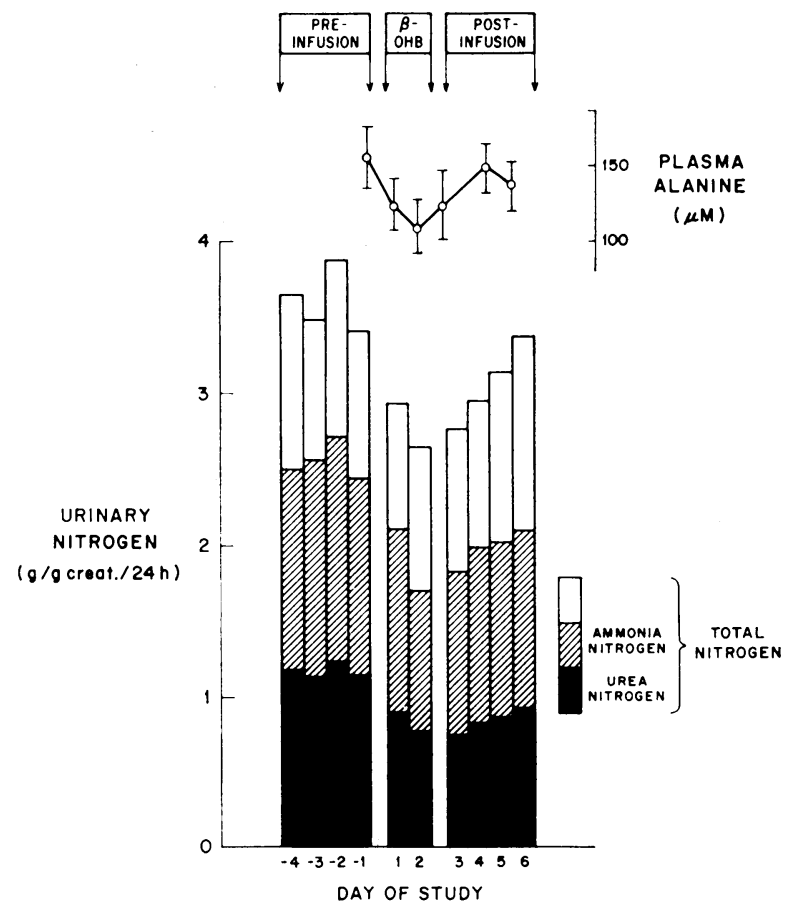

Figure 5 Effect of prolonged infusion of $\beta$-OHB (administered as 12-h infusions [9:00 a.m.-9:00 p.m.] on each of 2 consecutive days) on daily urinary nitrogen excretion and plasma alanine concentration during prolonged (5-10 wk) starvation. Total height of the bars represents total nitrogen, the urea and ammonia components of which are shown separately. Each bar represents the mean value for five subjects ( $\mathrm{SE}$ are given in the text). The values for total urinary nitrogen, urea, and ammonia on day 2 of the infusion and on the first postinfusion day were significantly different $(P<0.025)$ from the mean values during the preinfusion control period. Plasma alanine concentrations at termination of the infusions on days 1 and 2 were significantly reduced $(P<0.01$ and $P<0.025$, respectively) from the preinfusion control values.

$\mathrm{g} / \mathrm{g}$ creatinine per $24 \mathrm{~h}(P<0.005)$. On the first postinfusion day, urinary nitrogen excretion remained depressed as compared to the preinfusion control period, i.e., total nitrogen $2.77 \pm 0.38 \mathrm{~g} / \mathrm{g}$ creatinine per $24 \mathrm{~h}$ $(P<0.025)$, urea nitrogen $0.75 \pm 0.32 \mathrm{~g} / \mathrm{g}$ creatinine per 24 h $(P<0.025)$, and ammonia nitrogen $1.08 \pm 0.14$ $\mathrm{g} / \mathrm{g}$ creatinine per $24 \mathrm{~h}(P<0.05)$, and then gradually returned to preinfusion control levels. Changes in plasma alanine closely paralleled the changes observed in urinary nitrogen excretion (Fig. 5). The magnitude of the decrease in plasma alanine on the second infusion day $(29 \%)$ closely approximated the magnitude of the decline in nitrogen excretion $(26-34 \%)$.

\section{DISCUSSION}

The current data demonstrate that physiologic increments in blood ketone concentrations induced by infu- sion of $\mathrm{Na}$ DL- $\beta$-hydroxybutyrate are associated with a prompt reduction in plasma alanine concentration in normal and obese subjects. The magnitude and rate of decline in circulating alanine exceeded that of all other amino acids. The hypoalaninemic effect of the ketone infusions was demonstrable in fasted as well as postabsorptive subjects. In subjects fasted 3 days or $3-5 \frac{1}{2}$ wk, alanine levels, which were already reduced from prefast concentrations, fell an additional $30-48 \%$ after ketone infusion. Furthermore, the hypoalaninemic effect of prolonged infusions of ketones in fasted subjects was associated with a significant decline in urinary nitrogen excretion. That the changes in alanine levels did not reflect a nonspecific result of plasma volume expansion or diurnal variations is indicated by the failure to induce hypoalaninemia with equimolar infusions of sodium chloride (Fig. 2). In a like manner, the alkalinizing effect of the $\beta$-OHB cannot be implicated inasmuch as $\mathrm{NaHCO}_{3}$ administration was also without effect on plasma alanine concentration (Fig. 2).

The present findings are of particular interest with respect to glucose homeostasis and protein catabolism in starvation. Previous studies have shown that decreased hepatic gluconeogenesis and nitrogen excretion in prolonged fasting are a consequence of diminished availability of circulating alanine $(3,4)$. The degree of hypoalaninemia induced by a 6 -h infusion of ketones was comparable to the decline in basal alanine levels observed after prolonged starvation (Table II). When hypoalaninemia was maintained by prolonged infusion of ketones, a significant decline in urinary nitrogen excretion was observed which reverted to preinfusion levels after cessation of the infusion (Fig. 5). These data thus suggest that hyperketonemia may be a contributory factor in the development of hypoalaninemia and decreased protein catabolism observed in starvation. Ketones thus may serve a dual role in starvation, in replacing glucose as fuel for the brain (2) and in reducing substrate availability for gluconeogenesis. Evidence supporting a protein-sparing effect of ketones has recently been presented by Blackburn, Flatt, Clowes, and O'Donnell (19). These authors noted that nitrogen balance improved in proportion to hyperketonemia in postoperative patients receiving i.v. amino acids.

The current observations are also of interest with respect to the hypoalaninemia reported in normal pregnancy (20) and in ketotic hypoglycemia, a common disorder of blood glucose homeostasis observed in young children (21). In both circumstances, hypoalaninemia has been implicated in the pathogenesis of exaggerated starvation ketosis and hypoglycemia. The present data suggest that hypoalaninemia may be a consequence rather than a cause of the hyperketonemia observed in those conditions. 
Ketone-induced hypoalaninemia could result from a decrease in muscle outflow of this amino acid, an increase in hepatic uptake, or both (6). To the extent that ketone infusions cause a fall in blood glucose (18), a reduction in endogenous glucose production (22), and decreased nitrogen excretion, it is unlikely that augmented hepatic uptake of this key gluconeogenic precursor is responsible for the reduction in plasma alanine. On the other hand, the current findings of nitrogen sparing in association with decreased circulating alanine levels suggest a diminution in muscle release of this amino acid. Moreover, they may provide an explanation for the decrease in glucose production previously reported with ketone infusions (22).

With respect to the mechanism whereby ketones could affect muscle output of alanine, synthesis of this amino acid by muscle tissue has been demonstrated to be influenced by the availability of glucose-derived pyruvate $(23,24)$ and the rate of breakdown of the branched chain amino acids (valine, leucine, and isoleucine) (24). The latter are believed to be the source of the amino groups for alanine formation (24). Although the present study does not provide data on pyruvate concentrations in muscle, the ketone infusions were without effect on blood pyruvate levels (Fig. 1). On the other hand, physiologic increments in $\mathrm{Na}$ DL- $\beta$-OHB have been demonstrated to inhibit the oxidation of branchedchain amino acids (25). Furthermore, branched-chain amino acids have been demonstrated to decrease the rate of overall protein catabolism in isolated muscle (26). Interestingly, the prolonged ketone infusion resulted in a small, but significant, increment in isoleucine levels (Table III) and in no instance reduced the level of leucine. Ketone-induced hypoalaninemia and protein conservation thus may reflect inhibition of branchedchain amino acid oxidation in muscle.

The fall in plasma alanine and nitrogen excretion induced by ketone infusion occurred in the absence of changes in plasma insulin or glucagon. Transient increments in plasma insulin have been observed with acute bolus infusions of AcAc in man (27). However, previous investigators have also noted that continuous infusions of ketone acids fail to increase plasma insulin in peripheral blood $(18,28,29)$. Although growth hormone was not measured in the present study, other reports have shown that increased levels of growth hormone are without effect on total urinary nitrogen excretion in prolonged starvation (30).

In addition to the diminution in urea excretion, urinary ammonia loss also fell during the ketone infusions (Fig. 5). The principal nitrogenous precursor for renal ammonia production is glutamine (31), the concentration of which decreases during starvation (32). Further studies will be necessary to determine if ketone infusions influence glutamine levels in a manner comparable to alanine. In addition, in contrast to the situation with regard to alanine levels and urea excretion, a possible contribution of the mild alkalinizing effect of the ketone infusion in reducing urinary ammonia excretion cannot be excluded.

As starvation progressed, equimolar infusion of $\mathrm{Na}$ DL- $\beta$-OHB resulted in greater increments in blood ketone concentration (Fig. 3). In addition, whereas a stable concentration of total ketones was achieved in postabsorptive subjects within $30-60 \mathrm{~min}$, in the fasted group ketone levels rose progressively over $6 \mathrm{~h}$ (Fig. 3 ). The data thus suggest a progressive diminution or saturation in the rate of total ketone degradation during starvation. These findings are in agreement with previous conclusions based on observations of forearm uptake and splanchnic production of ketone bodies $(33,34)$ and the disappearance rate of bolus injections of AcAc (27).

Finally, it should be noted that the ketone infusion cmployed in the present study was the racemic mixture of $\beta$-OHB. The $\mathrm{L}(+)$-isomer does not naturally occur in mammalian species. Rat tissue homogenates are however, capable of utilizing the $\mathrm{L}(+)$-isomer via a series of reactions which bypass AcAc formation (35). It is not established whether this alternative pathway is active in man. The enzymatic method used to measure $\beta$-OHB precludes measurement of the $\mathrm{L}(+)$-isomer. It is thus possible that our data underestimate the concentrations of ketones necessary to produce hypoalaninemia. However, it should be noted that hypoalaninemia was observed at mean levels of $\mathrm{D}-(-)-\beta_{-} \mathrm{OHB}$ of 0.8 $\mathrm{mM}$ (Fig. 1) which are only one-sixth the levels achieved in prolonged fasting. Thus even a gross underestimate of total circulating ketones would not preclude an increment within the physiologic range with the infusion procedure employed in the present study.

\section{ACKNOWLEDGMENTS}

We thank Andrea Belous, William Sweet, and Ralph Jacob for their expert technical assistance and Tina Spinelli for her secretarial assistance. We are grateful to the nurses and staff of the General Clinical Research Center for caring for our patients.

This research was supported by grants AM 13526 and RR 125 from the National Institutes of Health.

\section{REFERENCES}

1. Felig, P., E. Marliss, O. E. Owen, and G. F. Cahill, Jr. 1969. Blood glucose and gluconeogenesis in fasting man. Arch. Intern. Med. 123: 293-298.

2. Owen, O. E., A. P. Morgan, H. G. Kemp, J. M. Sullivan, H. G. Herrera, and G. F. Cahill, Jr. 1967. Brain metabolism during fasting. J. Clin. Invest. 46: 15891595 . 
3. Felig, P., O. W. Owen, J. Wahren, and G. F. Cahill Jr. 1969. Amino acid metabolism during prolonged starvation. J. Clin. Invest. 48: 584-594.

4. Felig, P., T. Pozefsky, E. Marliss, and G. F. Cahill, Jr. 1970. Alanine: key role in gluconeogenesis. Science (Wash. D. C.). 167: 1003-1004.

5. Cahill, G. F., Jr., M. G. Herrera, A. P. Morgan, J. S. Soeldner, J. Steinke, P. L. Levy, G. A. Reichard, Jr., and D. M. Kipnis. 1966. Hormone-fuel interrelationships during fasting. J. Clin. Invest. 45: 1751-1769.

6. Felig, P. 1973. The glucose-alanine cycle. Metab. (Clin. Exp.). 22: 179-207.

7. Marliss, E. B., T. T. Aoki, R. H. Unger, J. S. Soeldner, and G. F. Cahill, Jr. 1970. Glucagon levels and metabolic effects in fasting man. J. Clin. Invest. 49: 2256-2270.

8. Owen, O. E., P. Felig, A. P. Morgan, J. Wahren, and G. F. Cahill, Jr. 1969. Liver and kidney metabolism during prolonged starvation. J. Clin. Invest. 48: 574 583.

9. Seltzer, H. S. 1971. Oral glucose tolerance tests. In Diabetes Mellitus: Diagnosis and Treatment. S. S. Fajans and K. E. Sussman, editors. American Diabetes Association, New York. 3: 101-106.

10. Dare, J. G., and G. A. Mogey. 1954. Rabbit responses to human threshold doses of a bacterial pyrogen. $J$. Pharm. Pharmacol. 6: 325-332.

11. Wise, J. K., R. Hendler, and P. Felig. 1973. Influence of glucocorticoids on glucagon secretion and plasma amino acid concentrations in man. J. Clin. Invest. 52: 2774-2782.

12. Williamson, D. H., J. Mellanby, and H. A. Krebs. 1962. Enzymic determination of $\mathrm{D}(-)-\beta$-hydroxybutyric acid and acetoacetic acid in blood. Biochem. J. 82: 90-96.

13. Bücher, T., R. Czok, W. Lamprecht, and E. Latzko. 1965. Pyruvate. In Methods of Enzymatic Analysis. H. U. Bergmeyer, editor. Academic Press, Inc., New York. 2nd edition. 253-259.

14. Hohorst, H. J. 1965. L-(+)-Lactate. Determination with lactic dehydrogenase and DPN. In Methods of Enzymatic Analysis. H. U. Bergmeyer, editor. Academic Press, Inc., New York. 2nd edition. 266-270.

15. Chaney, A. L., and E. P. Marbach. 1962. Modified reagents for determination of urea and ammonia. Clin. Chem. 8: 130-132.

16. Henry, R. J. 1964. Clinical Chemistry: Principles and Techniques. Harper \& Row, Publishers, New York. 1 st edition.

17. Snedecor, G. W., and W. G. Cochran. 1967. Statistical Methods. Iowa State University Press, Ames, Iowa. 6th edition.

18. Senior, B., and L. Loridan. 1968. Direct regulatory effect of ketones on lipolysis and glucose concentrations in man. Nature (Lond.). 219: 83-84.

19. Blackburn, G. L., J. P. Flatt, G. H. A. Clowes, and T. E. O'Donnell. 1973. Peripheral intravenous feeding with isotonic amino acid solutions, Am. J. Surg. 125: $447-454$

20. Felig, P., Y. J. Kim, V. Lynch, and R. Hendler. 1972. Amino acid metabolism during starvation in human pregnancy. J. Clin. Invest. 51: 1195-1202.

21. Pagliara, A. S., I. E. Karl, D. C. De Vivo, R. D. Feigen, and D. M. Kipnis. 1972. Hypoalaninemia : a concomitant of ketotic hypoglycemia. J. Clin. Invest. 51: 1440-1449.

22. Balasse, E., E. Couturier, and J. R. M. Franckson. 1967. Influence of sodium $\beta$-hydroxybutyrate on glucose and free fatty acid metabolism in normal dogs. Diabetologia. 3: 488-493.

23. Felig, P., and J. Wahren. 1971. Amino acid metabolism in exercising man. J. Clin. Invest. 50: 2703-2714.

24. Odessey, R., E. A. Kharallah, and A. L. Goldberg. 1974. Origin and possible significance of alanine production by skeletal muscle. J. Biol. Chem. 249: 7623-7629.

25. Buse, M. G., J. F. Biggers, K. H. Friderici, and J. F. Buse. 1972. Oxidation of branched chain amino acids by isolated hearts and diaphragm of the rat. The effect of fatty acids, glucose, and pyruvate respiration. $J$. Biol. Chem. 247 : 8085-8096.

26. Fulks, R. M., J. B. Li, and A. L. Goldberg. 1975. Effects of insulin, glucose, and amino acids on protein turnover in rat diaphragm. J. Biol. Chem. 250: 290-298.

27. Owen, O. E., G. A. Reichard, Jr., H. Markus, G. Boden, M. A. Mazzoli, and C. R. Shuman. 1973. Rapid intravenous sodium acetoacetate infusion in man. Metabolic and kinetic responses. J. Clin. Invest. 52: 2606-2616.

28. Fajans, S. S., J. C. Floyd, Jr., R. F. Knopf, and J. W. Conn. 1964. A comparison of leucine and acetoacetateinduced hypoglycemia in man. J. Clin. Invest. 43: 20032008.

29. Balasse, E., and H. A. Ooms. 1967. Changes in the concentrations of glucose, free fatty acids, insulin, and ketone bodies in the blood during sodium $\beta$-hydroxybutyrate infusions in man. Diabetologia. 4: 133-135.

30. Felig, P., E. B. Marliss, and G. F. Cahill, Jr. 1971 Metabolic response to human growth hormone during prolonged starvation. J. Clin. Invest. 50: 411-421.

31. Pitts, R. F. 1964. Renal production and excretion of ammonia. Am. J. Med. 36: 720-742.

32. Aoki, T. T., W. A. Müller, and G. F. Cahill, Jr. 1972. Hormonal regulation of glutamine metabolism in fasting man. In Advances in Enzyme Regulation. G. Weber, editor. Pergamon Press Ltd., Oxford. 10: 145-151.

33. Owen, O. E., and G. A. Reichard, Jr. 1971. Human forearm metabolism during progressive starvation. $J$. Clin. Invest. 50: 1536-1545.

34. Garber, A. J., P. H. Menzel, G. Boden, and O. E. Owen. 1974. Hepatic ketogenesis and gluconeogenesis in humans. J. Clin. Invest. 54: 981-989.

35. MoCann, W. P. 1957. The oxidation of ketone bodies by mitochondria from liver and peripheral tissues. J. Biol. Chem. 226: 15-22. 